\title{
Contrasting climate change in the two polar regions
}

\author{
John Turner ${ }^{1} \&$ Jim Overland ${ }^{2}$ \\ 1 British Antarctic Survey, High Cross, Madingley Road, Cambridge CB3 OET, UK \\ 2 Pacific Marine Environment Laboratory, National Oceanic and Atmospheric Administration, 7600 Sand Point Way NE, Seattle, WA 98115, USA
}

Keywords

Annular modes; Antarctic; Arctic; climate change; ozone hole.

Correspondence

John Turner, British Antarctic Survey, High Cross, Madingley Road, Cambridge CB3 OET,

UK. E-mail: J.Turner@bas.ac.uk

doi:10.1111/j.1751-8369.2009.00128.x

\begin{abstract}
The two polar regions have experienced remarkably different climatic changes in recent decades. The Arctic has seen a marked reduction in sea-ice extent throughout the year, with a peak during the autumn. A new record minimum extent occurred in 2007, which was $40 \%$ below the long-term climatological mean. In contrast, the extent of Antarctic sea ice has increased, with the greatest growth being in the autumn. There has been a large-scale warming across much of the Arctic, with a resultant loss of permafrost and a reduction in snow cover. The bulk of the Antarctic has experienced little change in surface temperature over the last 50 years, although a slight cooling has been evident around the coast of East Antarctica since about 1980, and recent research has pointed to a warming across West Antarctica. The exception is the Antarctic Peninsula, where there has been a winter (summer) season warming on the western (eastern) side. Many of the different changes observed between the two polar regions can be attributed to topographic factors and land/sea distribution. The location of the Arctic Ocean at high latitude, with the consequently high level of solar radiation received in summer, allows the icealbedo feedback mechanism to operate effectively. The Antarctic ozone hole has had a profound effect on the circulations of the high latitude ocean and atmosphere, isolating the continent and increasing the westerly winds over the Southern Ocean, especially during the summer and winter.
\end{abstract}

The fourth assessment report of the Intergovernmental Panel on Climate Change (IPCC) indicated that some of the largest climatic changes over the next century are expected to occur at high latitudes (Solomon et al. 2007). On this time scale, if concentrations of greenhouse gases continue to rise at the present rate, we can expect a large reduction in sea-ice extent in both polar regions, broadscale warming across the Arctic and Antarctic and greater high-latitude precipitation. However, over recent decades the changes observed in the two polar regions have been markedly different. Whereas the extent of late summer season sea ice in the Arctic has reached record minima, the Antarctic sea ice has increased in extent by a small amount. Near-surface air temperatures have increased in many parts of the Arctic, yet temperatures across much of the Antarctic have actually decreased, but with the Antarctic Peninsula warming at a rate as high as observed anywhere in the Southern Hemisphere. There is increasing evidence of enhanced melting on the periphery of Greenland, yet the Antarctic ice sheet appears to be essentially in balance.

The forcing by shortwave radiation is very similar in the two polar regions, and greenhouse gas concentrations are essentially the same in both areas. So the contrasting changes that have taken place must be a result of differences in the topography and land/sea distribution of the two regions, which result in markedly different atmospheric and oceanographic conditions, along with factors specific to each area, such as the major depletion of stratospheric ozone that has occurred above the Antarctic. In this paper we document the climatic changes that have taken place in recent decades, and consider our current knowledge of the mechanisms responsible for the changes. We also suggest future research needs. 


\section{The coupled elements of the polar climate systems}

Although record-breaking climatic events, such as the new minimum in Arctic sea-ice extent in September 2007, and the very large increase in surface temperature on the western side of the Antarctic Peninsula over the last 50 years, receive a great deal of attention in both scientific and popular literature, they should not be considered in isolation. Research in recent years has shown the highly coupled nature of the polar environments, with the atmosphere, ocean and cryosphere often playing a role in concert in establishing anomalous conditions. For example, changes in the atmospheric circulation can result in anomalies in the sea-ice extent, which in turn can affect the salinity of the ocean. Whereas atmospheric anomalies can be quite shortlived, changes to the ocean can persist for long periods, so that understanding individual events can require the consideration of changes in the whole system over an extended period.

A factor that has played a role in many of the atmospheric and oceanic changes observed at high latitudes in recent years has been shifts in the large-scale modes of variability of the climate system (Stammerjohn, Martinson, Smith, Yuan et al. 2008). Studies of atmospheric analyses have shown that the principal modes of variability in the atmospheric circulation of the extratropics consist of oscillations of mass (as measured by surface barometric pressure) between high and mid-latitudes (Thompson \& Wallace 2000). These can be observed as anomalies of opposite sign in mean sea-level pressure (MSLP), with periods of positive (negative) anomalies at high latitudes (mid-latitudes) developing before the anomalies reverse. These anomalies have a near-zonally symmetric or annular structure, and are known as the Southern Annular Mode (SAM; also known as the highlatitude mode or the Antarctic Oscillation) and the Northern Annular Mode (NAM, which is related to the North Atlantic Oscillation) in the south and north, respectively. The NAM and SAM can be seen in many parameters measured at high latitudes besides surface pressure, including temperature, geopotential height and zonal wind. When the annular modes are more positive, atmospheric pressures are lower at high latitudes and higher in mid-latitudes, which results in a strengthening of the westerly winds. Changes in the annular modes can therefore have major implications for oceanographic conditions.

Observational and modelling studies have shown that the SAM contributes a large proportion (ca. 35\%) of the Southern Hemisphere climate variability on a large range of timescales, from daily (i.e., Baldwin 2001) to decadal
(Kidson 1999), and is also likely to drive the large-scale circulation of the Southern Ocean. An index of the SAM has been constructed from the pressure difference between the latitudes $40^{\circ} \mathrm{S}$ and $65^{\circ} \mathrm{S}$ (Marshall 2003), allowing its changes since 1957 to be investigated. The record can be extended further back using proxy data, such as the tree-ring record (Jones $\&$ Widmann 2003). It is possible to examine much longer-term changes in the NAM as meteorological observations from around the North Atlantic are available dating back to around the middle of the 19th century.

The two polar regions are also affected by a number of different modes of variability (Simmonds 2003; Yuan \& Li 2008). Tropical atmospheric and oceanic conditions can affect high latitudes, with signals of the El NiñoSouthern Oscillation (ENSO) being transferred polewards via the Pacific South American Association (PSA) (Simmonds \& Jacka 1995; Yuan \& Martinson 2000; Yuan 2004) and the Pacific North American Association (PNA) (Turner 2004). These two modes are characterized by a series of alternating positive and negative mean sea-level pressure anomalies, extending from the west-central equatorial Pacific into both hemispheres. High-low latitude links that operate on longer time scales also exist, such as the Pacific Decadal Oscillation (PDO) (Zhang et al. 1997). The PDO is important in influencing the climate of Alaska, and changes in the PDO have been linked to the recent warming across the region. It has even been shown to modulate Antarctic precipitation (Monaghan \& Bromwich 2008). The impacts from the positive and negative phases of the PNA and NAM can act independently or simultaneously in any given winter, with trends in Arctic cyclones and variations influencing sea-ice cover (Simmonds et al. 2008). As the PNA and NAM represent less than $50 \%$ of the interannual MSLP variability, a third type of pattern can arise, such as the anomalous meridional flow into the western Arctic observed in the first part of the 21 st century (Overland et al. 2008).

The PSA has a strong influence on the climate of the Antarctic Peninsula/southern South America region, whereas the PNA affects the Aleutian Low. Conditions in the tropical Indian Ocean have also been linked to climatic change in the North Atlantic (Hoerling et al. 2001; Hoerling et al. 2004). However, the robustness of these statistical links (teleconnections) can change over time (Fogt \& Bromwich 2006), so that very similar tropical El Niño or La Niña events can give quite different extratropical responses. There are also interactions between the SAM and ENSO that further complicate the linkages of the tropical and high-latitude climates. However, there is still debate over links between the ENSO and the NAM (Quadrelli \& Wallace 2002). 


\section{Recent changes in the polar environment}

\section{Atmospheric circulation}

The Arctic. In the Northern Hemisphere, we have a long record of the variations in the NAO/NAM (Fig. la). In the late 19th and early 20th centuries there were fluctuations in the index, and periods of positive anomaly, such as around 1910, but no overall trend. The most marked trend has been from the mid-1960s to the mid-1990s, when the index shifted from a large negative to a large positive anomaly. This change resulted in a strengthening of the mid-latitude westerlies, and the advection of warm air from the North Atlantic into the Arctic Ocean and northern Russia. As in the south, increasing levels of greenhouse gases can shift the NAM into its positive phase. However, since the mid-1990s, at a time of record levels of greenhouse gases, the NAM has reverted to more neutral conditions, indicating the complex nature of climate change.

The Arctic has not experienced the level of stratospheric ozone loss that has been observed in the Antarctic, as there is more meridional heat transport in the north, and hence stratospheric temperatures are not (a)

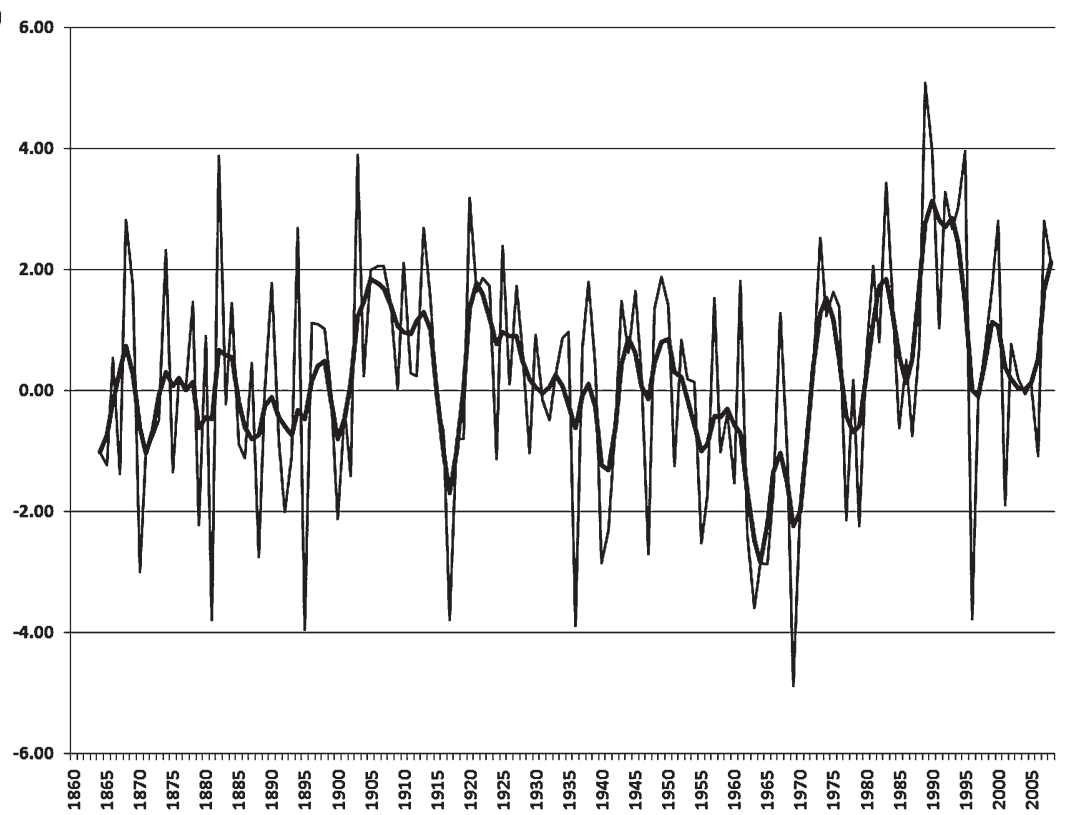

(b)

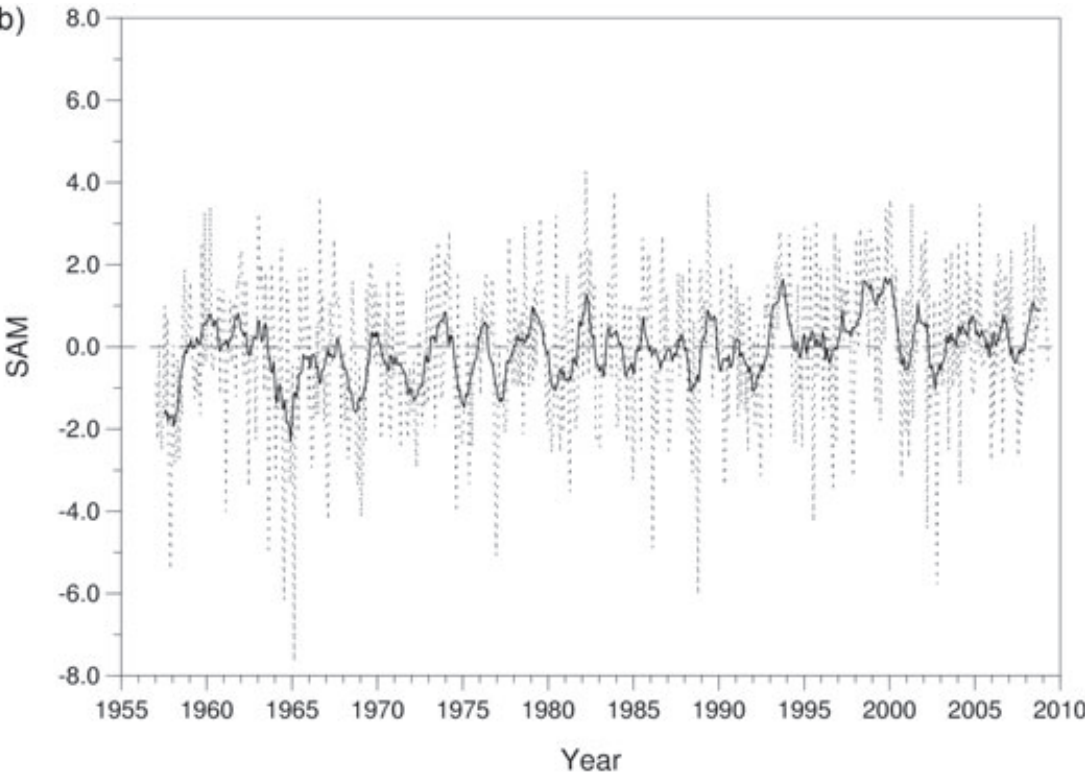

Fig. 1 (a) The winter season North Atlantic Oscillation index based on station data. The thick line is the 5-year running mean. (Data from the Climate and Global Dynamics group, National Center for Atmospheric Research, Boulder, CO, USA.) (b) Monthly values of the Southern Annular Mode (SAM) index. The thick line is a 12-month running mean. (From http:// www.antarctica.ac.uk/met/gjma/sam.html; figure courtesy of Dr Gareth Marshall, British Antarctic Survey.) 
cold enough for large-scale ozone destruction. However, there has been some ozone loss, and Volodin \& Galin (1999) found a link between ozone depletion and NAM trends. This finding has not been reproduced in other models, and simulations forced by Randel \& Wu's (1999) ozone trends did not show a significant Northern Hemisphere circulation response, suggesting that the much weaker ozone depletion observed in the Northern Hemisphere has not been an important driver of circulation changes there.

The Aleutian Low is one of the main features of atmospheric circulation in the Northern Hemisphere during winter, with a controlling influence on North Pacific Ocean circulation, Bering Strait sea-ice extent and western North American surface climate (Zhu et al. 2007). There has been a statistically significant 20th century shift to a deeper and more poleward winter Aleutian Low, which has been attributed to anthropogenic greenhouse gases and sulphate aerosols (Fyfe, pers. comm. 2008).

The Antarctic. The SAM and NAM change as a result of natural climate variability, and also in response to various anthropogenic forcing factors. Since 1957 the SAM has shifted to more positive conditions (Fig. 1b), with the largest change being during the summer and autumn seasons. Marshall et al. (2004) demonstrated that the upward trend in the summer SAM index during recent decades is inconsistent with simulated internal variability in the Hadley Centre General Circulation Model, which suggests an external cause. Experiments with climate models have suggested that the SAM has changed most because of the development of the Antarctic ozone hole (Sexton 2001; Gillet \& Thompson 2003). The polar vortex is most pronounced in the winter stratosphere, when the air above the continent is extremely cold. The destruction of stratospheric ozone above the Antarctic mostly takes place during the spring (Farman et al. 1985), thereby cooling the stratosphere and strengthening the polar vortex at this level during this season. But the loss of springtime ozone as a result of the "ozone hole" has also cooled the stratosphere through the summer months. This in turn has resulted in a lower mean sea-level pressure in the Antarctic at this time of year, thereby shifting the SAM into its positive phase (Thompson \& Solomon 2002). The changes in the SAM have resulted in a poleward contraction, and an increase of about $20 \%$ in the strength of the circumpolar westerly winds during autumn. In addition, the shift to a positive phase of the SAM has given weakened descent and colder temperatures over most of Antarctica, and has increased the production of coastal sea ice.
Increasing concentrations of greenhouse gases have also been shown to move the SAM into its positive phase (Fyfe et al. 1999; Kushner et al. 2001; Stone et al. 2001). However, model experiments suggest that the increase of greenhouse gases make a smaller contribution to the change than stratospheric ozone depletion (Arblaster $\&$ Meehl 2006).

Since the late 1970s, El Niño events have become more frequent and stronger. However, it has been difficult to find high-latitude climate changes than can be attributed to these alterations in the tropical circulation. Around the Antarctic, a shift to more El Niño events would tend to promote a stronger PSA pattern, with more highpressure/blocking events to the west of the Antarctic Peninsula. However, the available atmospheric analyses would suggest that there has been the reverse of this trend, with more storms in the area, again indicating the highly nonlinear links between the high- and lowlatitude areas.

Pezza et al. (2008) have recently proposed that there is an organized hemispheric cyclone pattern associated with the ENSO, the SAM, sea-ice extent and rainfall anomalies in Southern Australia. They suggest that the SAM and sea-ice extent are interlinked as part of a complex physical system that is best understood as a coupled mechanism.

\section{Ocean circulation and water masses}

The Arctic Ocean. Detecting changes in ocean circulation and water masses is more difficult than detecting changes in the atmosphere because of the lack of in situ observations in earlier decades. For example, no data exist from large areas of the Southern Ocean prior to the 1950s, a problem that persisted up to the advent of the satellite era in the 1970s and 1980s. Nevertheless, some indications of change are apparent.

Some of the largest oceanic changes have been observed in the Arctic Ocean. Here, there has been an increase in river discharge into the ocean from northern Eurasia since the mid-1930s, which has contributed to a marked freshening of the ocean (Peterson et al. 2008). This has happened in parallel with rising air temperatures (Johannessen et al. 2004), and greater snowfall across Eurasia when the NAM was in its positive phase (Min et al. 2008). But there has been decreasing river discharge in eastern Canada over the period 1964-2003, probably also tied to trends in the NAM (Déry et al. 2005). But on the other side of the continent, the Mackenzie River in Western Canada shows no long-term trend (Abdul \& Burn 2006). Discharge trends are greatest in the north, where the permafrost is most extensive and is melting. 
Subsurface layers within the Arctic Ocean are sensitive to the penetration of heat from Atlantic Water (AW) and Pacific Water (PW) via the Fram and Bering straits. Expeditions during the 1990s and 2000s measured variations in the heat content of AW, indicating a peak warming near the North Pole in 1995, a minimum in 2005 and a new warming pulse thereafter (Steele \& Boyd 1998; Morison et al. 2002). During the period 1965-1995, as the NAM index rose, warming was observed from AW advection into the Barents/Kara seas, and from PW advection into the Chukchi and western Beaufort seas. Also during this period, winter sea-ice transport away from the eastern Siberian shelves created thin ice that melted quickly during summer, leading to a longer summer open-water period, during which solar energy warmed the ocean. Recent ocean surface warming in the Beaufort/Chukchi/East Siberian seas since 2002 seems forced more by shortwave energy absorption than by northward-flowing ocean advection, although more in situ data are needed to confirm this.

The Southern Ocean. Over recent decades certain parts of the Southern Ocean have changed very rapidly, but the pattern and physical nature of the changes are complex, and a number of mechanisms and feedbacks are believed to be implicated.

On the large scale, the waters of the Antarctic Circumpolar Current (ACC) have warmed more rapidly than the global ocean as a whole. Temperature records from autonomous floats drifting at depths of between 700 and $1100 \mathrm{~m}$ during the 1990s were collated and examined by Gille (2002), who compared these data with earlier shipbased temperature measurements from the 1950s. She identified a large-scale warming of the ACC at this depth of around $0.2^{\circ} \mathrm{C}$ (Fig. 2). This work has recently been extended to show that the warming is greatest near the surface, where it has been as large as $1^{\circ} \mathrm{C}$. The temperature rise has not been constant, with the records showing a large shift in the upper ocean during the 1960s (Gille 2008). It was also suggested that the warming could be a result of a southwards shift of the ACC current cores, essentially reflecting a redistribution of heat rather than an overall temperature increase.

The reasons for the warming of the circumpolar Southern Ocean are not known unambiguously, and it is likely that multiple processes may have played a role. The shift of the SAM into its positive phase (Marshall 2003), with a subsequent increase in eastward wind stress over the Southern Ocean, and a shift in the band of maximum wind stress southwards, has had a major impact on the marine environment. It has resulted in a reduction in the efficiency of the Southern Ocean $\mathrm{CO}_{2}$ sink, associated

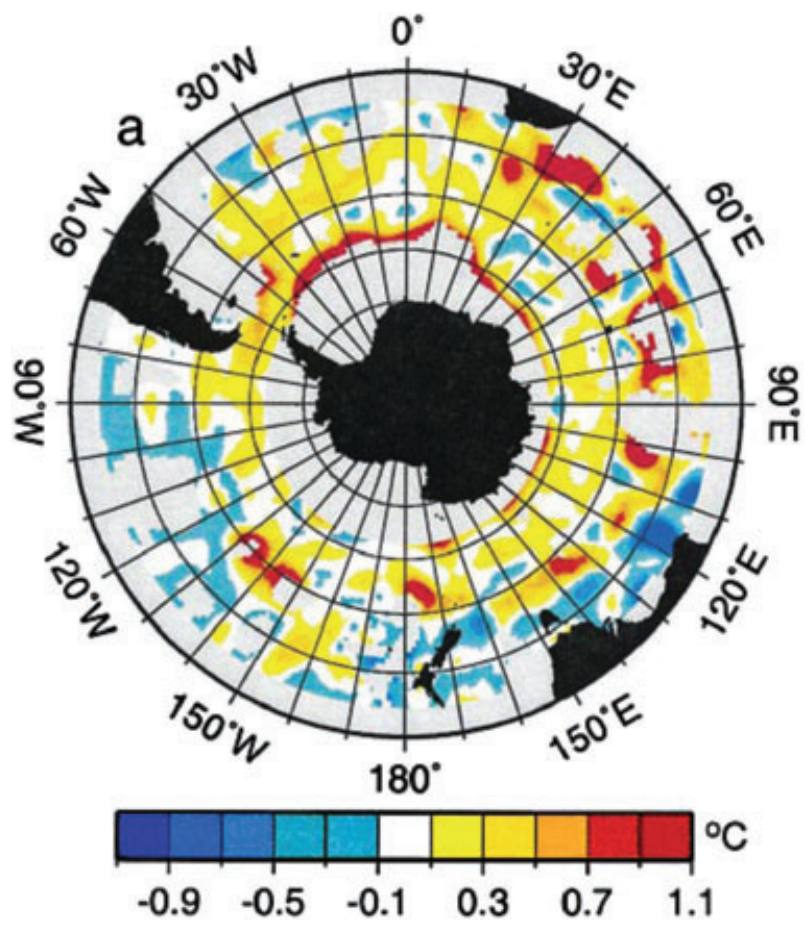

Fig. 2 Regions of warming of the Southern Ocean at depth (ca. 700$1100 \mathrm{~m}$ ) in ${ }^{\circ} \mathrm{C}$, derived by differencing temperature records from float data collected in the 1990s, with historical data collected by ships in previous decades. (From Gille 2003.)

with changes in upwelling and mixing (Le Quéré et al. 2007). The stronger westerlies could also have led to greater ocean eddy activity, and a consequent increase in the poleward eddy heat flux (Meredith \& Hogg 2006; Hogg et al. 2008). In addition, based on climate modelling studies, it has been suggested that the stronger winds over the Southern Ocean may be leading to an acceleration of the ACC (Hall \& Visbeck 2002; Fyfe \& Saenko 2006). It has been hypothesized, and supported by coarseresolution climate modelling studies, that the ACC may have moved southwards in response to the change in the SAM (Oke \& England 2004; Fyfe \& Saenko 2006), effectively bringing warmer water further south, and leading to an apparent warming. This suggestion is in line with the work of Gille (2002).

There is good observational evidence that the strength of the ACC does depend on the SAM on timescales from days and weeks (Aoki 2002; Hughes et al. 2003) to years (Meredith et al. 2004), but there is currently no evidence of a sustained, long-term increase in transport. This may result from the lack of a suitable monitoring system, but available indications do suggest that any change in transport over the past few decades have been small, and typically of the order of only a few sverdrup. 
A further process that could have contributed to the warming of the Southern Ocean is increased atmosphereto-ocean heat flux associated with raised levels of radiative greenhouse gases in the atmosphere, and modelling studies have indicated that the rate of Southern Ocean warming would have been even higher, but for the masking effects of volcanic and other aerosols (Fyfe 2006).

South of the ACC there are also major changes taking place. A very significant freshening of the waters in the coastal region between the Amundsen Sea and the Adélie Coast has been noted in recent decades (Jacobs et al. 2002), which could be of a comparable magnitude to the Great Salinity Anomaly of the North Atlantic (Dickson et al. 1988). The cause of the freshening is believed to involve the increased melt of glacial ice from adjacent regions of Antarctica (Jacobs et al. 2002), and it has been theorized that the excess heat causing this melt has come from the increasing ocean temperatures (Walker et al. 2007).

There is also evidence of a change in the hydrological cycle affecting both northern and southern branches of the global meridional overturning circulation. The observed freshening is not confined to the upper layers, but has been identified in some active areas of Antarctic Bottom Water formation, most notably in the Ross Sea (Rintoul 2007).

Regionally there has been a very strong warming in the ocean areas to the west of the Antarctic Peninsula, where the summertime surface ocean temperatures have warmed by more than $1{ }^{\circ} \mathrm{C}$ since the 1950s, with an accompanying increase in salinity (Meredith $\delta$ King 2005). These changes reflect the well-known increase in atmospheric temperature (King 1994) and reduction in sea ice at this location (Comiso \& Nishio 2007).

\section{Temperature changes}

The Arctic. There is large interannual and decadal temperature variability in both polar regions, which makes detection of trends difficult, especially as the length of the climate records are shorter than those for mid-latitude areas. However, we are fortunate in the Arctic in having 59 stations with continuous records of near-surface temperature that start around 1930-1940, with 15 that extend back to 1900 and three that even start in the middle of the 19th century. The temperature records from these 59 stations for January are shown in Fig. 3, along with a map indicating the locations of the stations.

This figure shows the complexity of temperature changes that take place on a range of timescales. Decades of warmer or colder conditions can be found throughout the records, followed by switches back to more average conditions. Large anomalies often occur across a range of longitudes, but are very rarely found all the way around the Arctic.

Overall, Fig. 3 shows generally warm temperatures for the 1990s, which is consistent with the global trend, whereas over the 1930s-1950s there were more regional/ temporal episodic warm events. The record of Arctic temperatures shows that it has warmed twice as much as the global mean warming, but the Arctic changes are neither spatially nor temporally uniform. For the central Arctic, the largest temperature trends over 1979-1995 occurred in the spring, the next largest trends occurred in winter, and trends for summer and autumn were much smaller (Serreze et al. 2000). With a major loss of summer sea ice in 2005-08, the anomalous autumn surface air temperatures are now $5^{\circ} \mathrm{C}$ above normal over much of the central Arctic.

In terms of annual mean surface temperature (Fig. 4), north-western North America and central Siberia have experienced the greatest temperature rises over the last 50 years. The warming across Alaska and northern Canada is mainly the result of a sudden warming in the mid-1970s, when there was a shift in the nature of the PDO, which deepened the Aleutian Low, thereby giving warmer conditions across Alaska.

The Antarctic. Many of the in situ climate records for the Antarctic start around the time of the International Geophysical Year (IGY) in 1957/58, when a number of year-round research stations were established. The 50 -year records from these stations indicate the complex temperature changes that have taken place (Turner et al. 2005) (Fig. 5a). This figure shows a pattern of large warming in the annual mean temperature on the western and northern parts of the Antarctic Peninsula, with Vernadksy (formerly Faraday) Station having the largest statistically significant $(<5 \%$ level $)$ trend, at $+0.56^{\circ} \mathrm{C}$ per decade from 1951 to 2000 . Rothera Station, some $300 \mathrm{~km}$ to the south of Vernadksy, has a larger annual warming trend, but the shortness of the record and the large interannual variability of the temperatures renders the trend statistically insignificant. The region of marked warming extends from the southern part of the western Antarctic Peninsula north to the South Shetland Islands, but the magnitude of the warming decreases northwards, away from Vernadksy. At Orcadas, in the South Orkney Islands, a 100 -year record shows a warming trend of only $+0.20^{\circ} \mathrm{C}$ per decade.

Most of the Antarctic research stations are located around the edge of the continent, and we have the most reliable information on temperature change at these sites. 


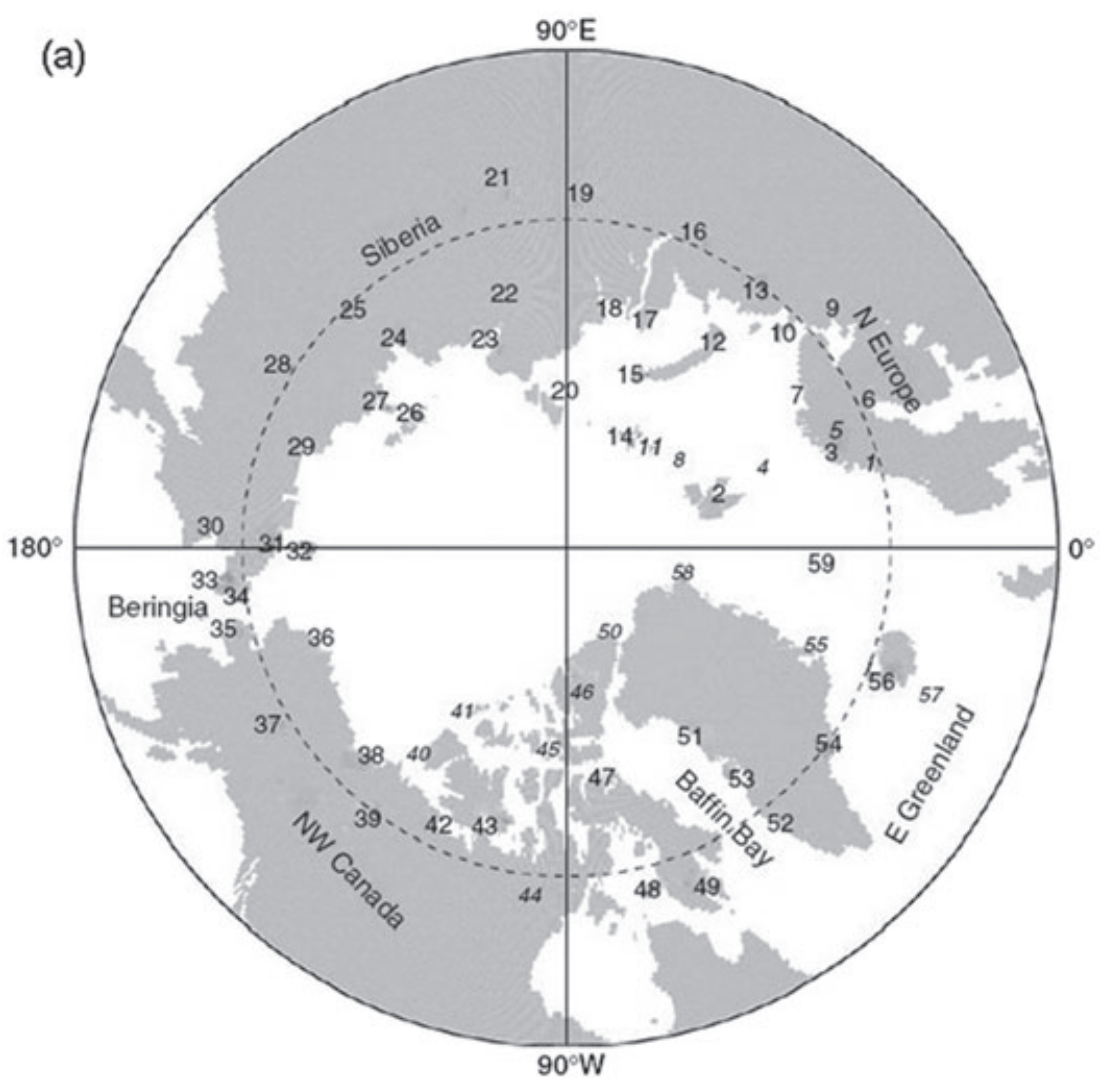

(b) $\quad 1357911131517192123252729313335373941434547495153555759$

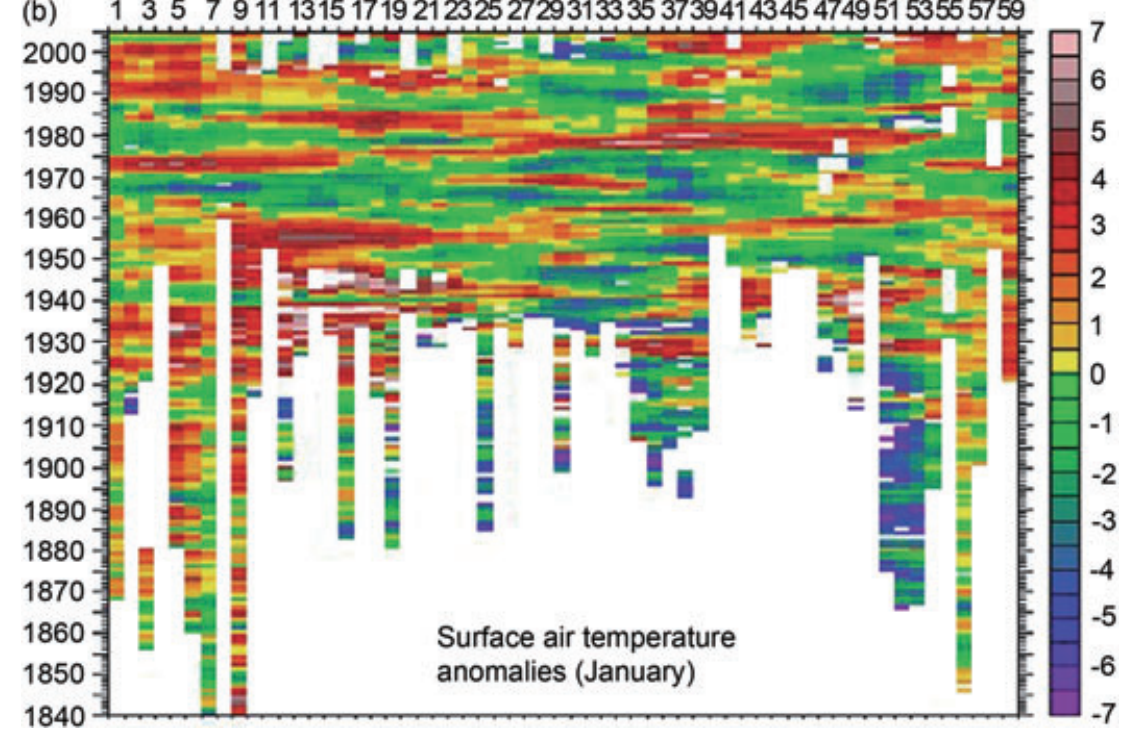

Fig. 3 (a) The locations of the 59 stations with long records in the Arctic. The station names are provided in Overland et al. (2004). (b) Surface temperature anomaly values for the 59 Arctic weather stations for January, relative to the 1961-1990 mean for each station. (Illustrations updated from Overland et al. 2004.)
However, a number of attempts have been made to extrapolate the trends from the locations of the stations to the data-sparse interior areas of the continent (Chapman \& Walsh 2007; Monaghan, Bromwich, Chapman et al. 2008). Figure $5 b$ shows the linear trends in annual mean surface temperature for the period 1958-2002, as determined in the Chapman $\&$ Walsh (2007) study. This highlights the marked contrast in temperature between the Antarctic Peninsula and the rest of the continent.

Recently, the available in situ staffed station and automatic weather station temperature observations have been used in conjunction with satellite-derived surface 
Fig. 4 Linear trends in the annual surface temperature for 1950-2008. (From http:// data.giss.nasa.gov/gistemp/maps/; courtesy of the National Aeronautics and Space Administration/Goddard Institute for Space Studies.)
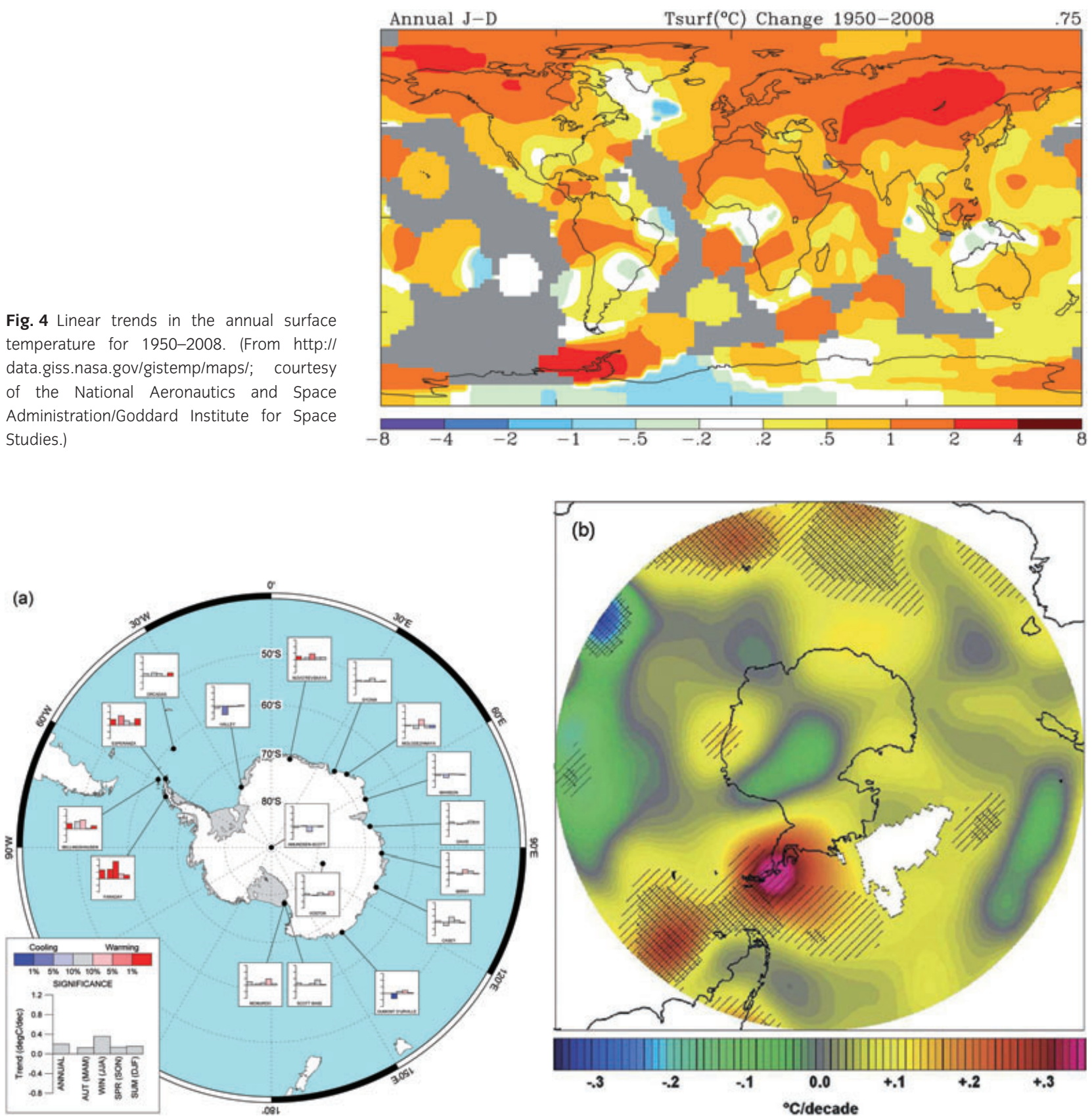

Fig. 5 (a) Annual and seasonal near-surface temperature trends, 1951-2006, for Antarctic stations with long in situ records (minimum 35 years). The trends are for the full length of each record. The colours indicate the statistical significance of the trends. Trends were computed for the full length of each record. Most stations started reporting around the time of the International Geophysical Year in 1957/58. Autocorrelation was taken into account in computing the significance levels. (Figure courtesy of Dr Gareth Marshall, British Antarctic Survey.) (b) Linear trends of annual mean surface air temperature $\left({ }^{\circ} \mathrm{C}\right.$ per decade) for the period 1958-2002. Greens and blues denote cooling; yellows and reds denote warming. Significant trends are indicated by hatching (95\% single hatching; 99\% cross-hatching). (From Chapman \& Walsh 2007.)

skin temperatures to estimate temperature trends across the interior regions of the continent, where data are sparse (Steig et al. 2009). The study found that there had been a significant warming across much of West Antarctica, with trends exceeding $0.1^{\circ} \mathrm{C}$ per decade, with the greatest warming having been during the winter and spring.

On a seasonal basis, the largest changes have been a winter (summer) warming on the western (eastern) side of the Antarctic Peninsula. At Vernadksy, the warming 

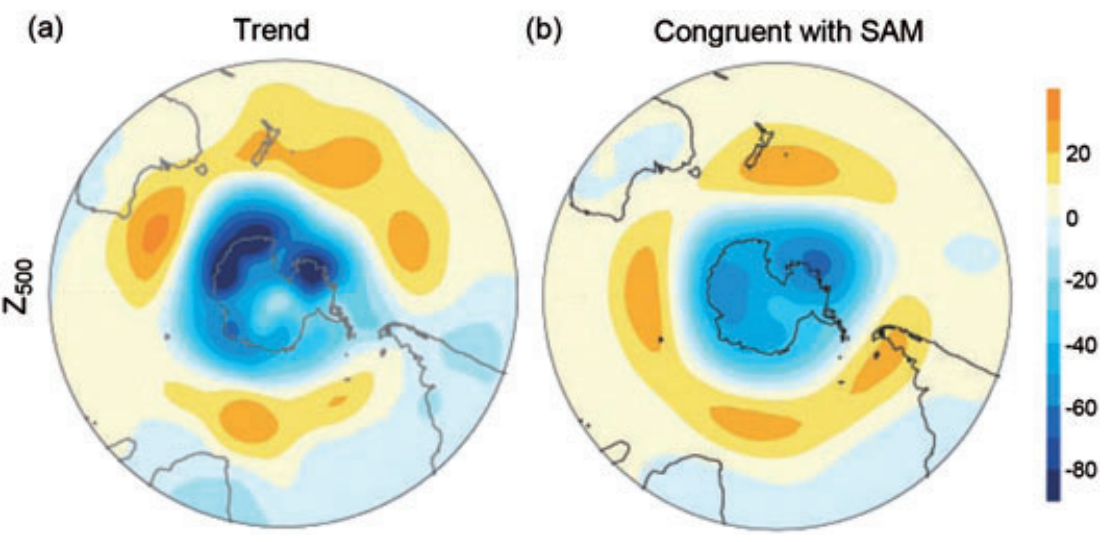

Fig. 6 (a) December-May linear trends in surface temperature (1969-2000) and $925-\mathrm{hPa}$ wind (1979-2000). (b) The contribution of the Southern Annular Mode to the trends. (From Thompson \& Solomon 2002. Reprinted with permission of the American Association for the Advancement of Science.) during winter has been $5^{\circ} \mathrm{C}$ over the last 50 years, and is consistent with the oceanic warming noted earlier. At this location there is a high correlation between the temperature and the winter sea-ice extent over the AmundsenBellingshausen Sea, suggesting greater sea-ice cover in the middle of the 20th century, and a progressive reduction since this time. The reasons for the greater sea-ice extent in the 1950s and 1960s are not known with certainty, but may have been linked to weaker/fewer storms to the west of the peninsula, and greater atmospheric blocking. A greater frequency of blocking anticyclones would have meant weaker northerly winds to the west of the Antarctic Peninsula, allowing the sea ice to advance farther north during the winter, and giving colder temperatures on the western side of the peninsula. At present it is not known whether the western peninsula warming is a result of natural climate variability, or whether it has an anthropogenic origin or component.

On the eastern side of the Antarctic Peninsula the largest warming has been observed during the summer months, and has been associated with the strengthening of the circumpolar westerlies as the SAM has shifted into its positive phase (Marshall et al. 2006). Stronger winds have resulted in enhanced temperature advection and more relatively warm, maritime air masses crossing the peninsula and reaching the low-lying ice shelves. Higher temperatures on the ice shelves will also be a result of adiabatic descent and warming of the winds crossing the Antarctic Peninsula topography.

Around the rest of the coastal region of the continent there have been few statistically significant changes in surface temperature over the last 50 years (Fig. 5a). However, the Amundsen-Scott Station, at the South Pole, has shown a statistically significant cooling in recent decades that is thought to be a result of fewer maritime air masses penetrating into the interior of the continent.

Since the development of the Antarctic ozone hole in the early 1980s, the resultant changes in the SAM have had a major impact on Antarctic temperatures. Figure 6 shows the December-May surface temperature trends, and the contribution of the SAM to the trends. This shows that over the summer-autumn period, the change of the SAM has resulted in a pattern of warming across the Antarctic Peninsula and a cooling around much of the coast of East Antarctica. van den Broeke \& van Lipzig (2004) argued that the reason for the winter cooling over East Antarctica during periods of high SAM index is the greater thermal isolation of Antarctica, resulting from increased zonal flow, decreased meridional flow and an intensified temperature inversion on the ice sheet because of weaker near-surface winds. For the period 1957-2004 the estimated change in Antarctic nearsurface temperatures in autumn caused by the upward trend in the SAM index exceeds $1.0^{\circ} \mathrm{C}$ at seven of 14 stations with long records. Without the loss of stratospheric ozone over the last 30 years, Antarctic warming may well have been more extensive.

Ice core proxy reconstructions of Antarctic surface temperatures provide an extremely important means of extending the climate record back into the preinstrumental period. Such data show that in the past few decades the temperatures have moved outside the range of variability established over the past 1200 years (Mayewski \& Maasch 2006).

The Antarctic radiosonde temperature profiles collected since the IGY indicate that there has been a warming of the winter troposphere and cooling of the stratosphere over the last 30 years. The data show that regional midtropospheric temperatures have increased most around the 500-hPa level, with statistically significant changes of $0.5-0.7^{\circ} \mathrm{C}$ per decade (Fig. 7 ), which is the largest temperature increase at this level on Earth. The spatial pattern of the warming can be appreciated from the 500$\mathrm{hPa}$ temperature trends in the European Centre for Medium-range Weather Forecasts (ECMWF) reanalysis fields (Turner et al. 2006), although it should be noted 
Fig. 7 Trends in the 500-hPa temperature over the period 1979-2001 from the European Centre for Medium-Range Weather Forecasts 40-year reanalysis, showing tropospheric warming around the $5-\mathrm{km}$ level. The contours are in ${ }^{\circ} \mathrm{C}$ per decade. (From Turner et al. 2006. Reprinted with permission of the American Association for the Advancement of Science.)

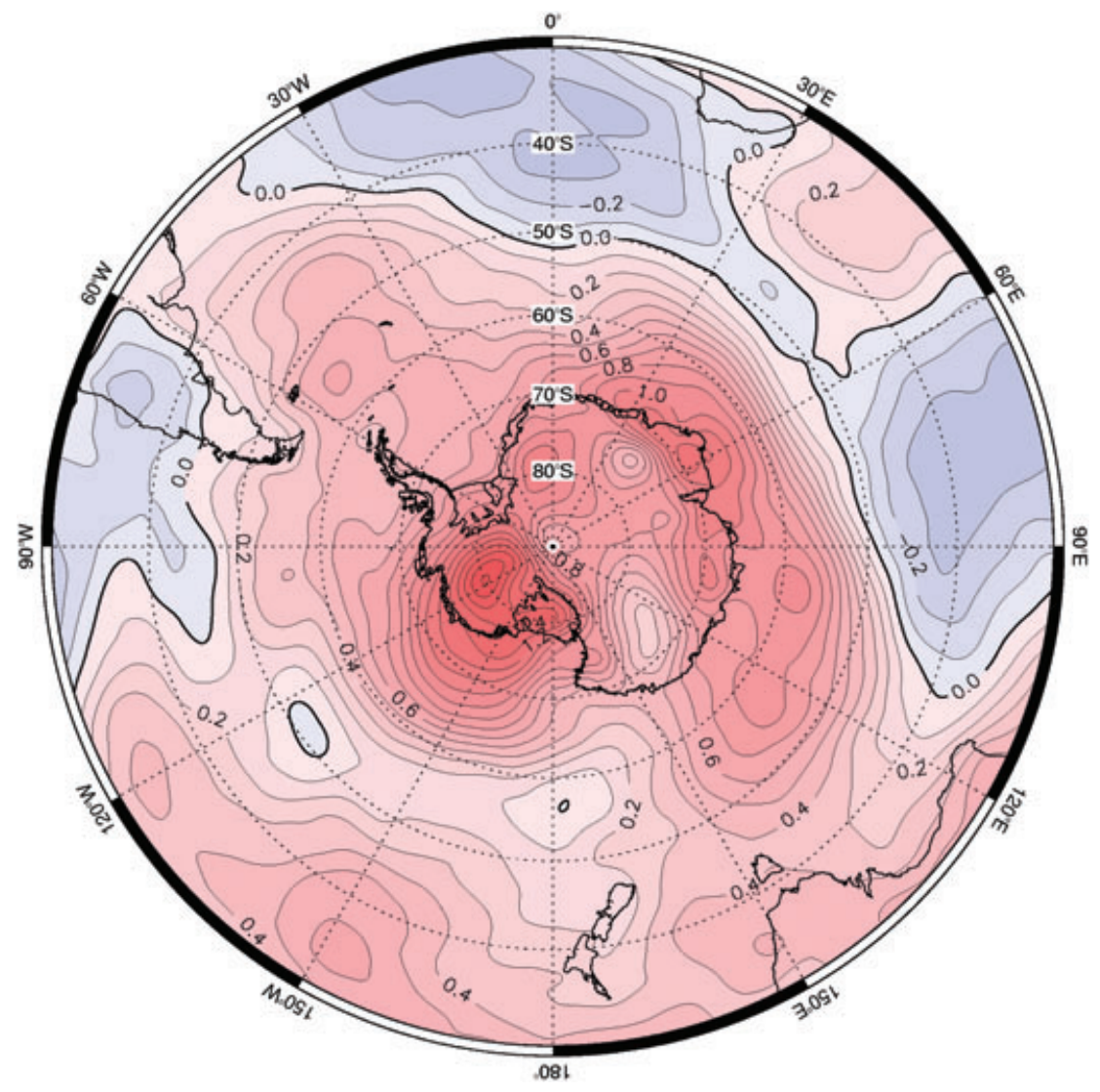

that the trends here are a little larger than in the radiosonde data because of a cold bias in the early part of the reanalysis data set. Recently, the Antarctic midtropospheric warming has been identified in the satellite Microwave Sounder Unit data (Johanson \& Fu 2007).

\section{Precipitation}

There are many problems in measuring solid precipitation at high latitudes, and gauge undercatch is a significant problem, especially in winter. So it is difficult to determine the changes in precipitation over recent decades. But, overall, there does seem to have been a recent increase in precipitation at certain locations, such as central Siberia, which is consistent with the positive NAM during this period, and the greater penetration of maritime air masses into the region. These trends are more evident from snow-depth records than from precipitation records, but are also consistent with the greater input of freshwater into the Arctic Ocean.

From a modelling point of view, all 21 IPCC fourth assessment report climate models, when run over the second half of the 20th century, have an increasing trend in ensemble mean precipitation across the Antarctic (Bracegirdle et al. 2008). Winter trends are similar to annual means, but summer shows no systematic changes.

In the Antarctic, the switch of the SAM into more positive conditions, with the consequent strengthening of the circumpolar vortex, is thought to have given drier conditions over large parts of West Antarctica, the Ross Ice Shelf and the Lambert Glacier region, and wetter conditions elsewhere (van den Broeke \& van Lipzig 2004). However, in situ measurement of precipitation on the Antarctic continent is very difficult, and much of our knowledge of precipitation variability and change has come from ice cores, from which it can be difficult to determine seasonal change. A major study into changes in Antarctic accumulation (Monaghan et al. 2006) concluded that there had been no statistically significant change in accumulation across the continent since the IGY, although there has been variability in the firn (Helsen et al. 2008). However, on longer timescales, and for limited areas, there are indications of change. For example, a new ice core from the south-west corner of the Antarctic Peninsula has shown that there has been a doubling of the accumulation in that region since about 1850 (Thomas et al. 2008). 


\section{Sea ice}

The Arctic. The marked decrease of Arctic sea-ice extent in recent years has been one of the most publicized aspects of polar climate change, and has been widely reported in the popular press as well as the scientific literature. The loss of ice has been greatest in September (Fig. 8), with a decrease of over $10 \%$ per decade for the period 1979-2006. In September 2007 the extent of Arctic sea ice reached a new minimum of 4.1 million $\mathrm{km}^{2}$ (Fig. 9), which was 39\% below climatology, and some $23 \%$ below the previous minimum in 2005. Although a progressive decrease of Arctic sea ice had been predicted by climate models for a number of years, most scientists were surprised by the dramatic sea-ice decline in 2007.

The ice appears to have reached a minimum in 2007 because of a long chain of events stretching back to the 1990s. The age, area and thickness of the ice had decreased in recent years as a result of the "flushing" of much of the ice out of the Arctic Basin in the early 1990s, which pre-conditioned the decline (Nghiem et al. 2007). The NAM was particularly strong and positive from 1989 to 1995, which advected a considerable volume of multiyear ice out of the Arctic into the Atlantic, so that the (a)

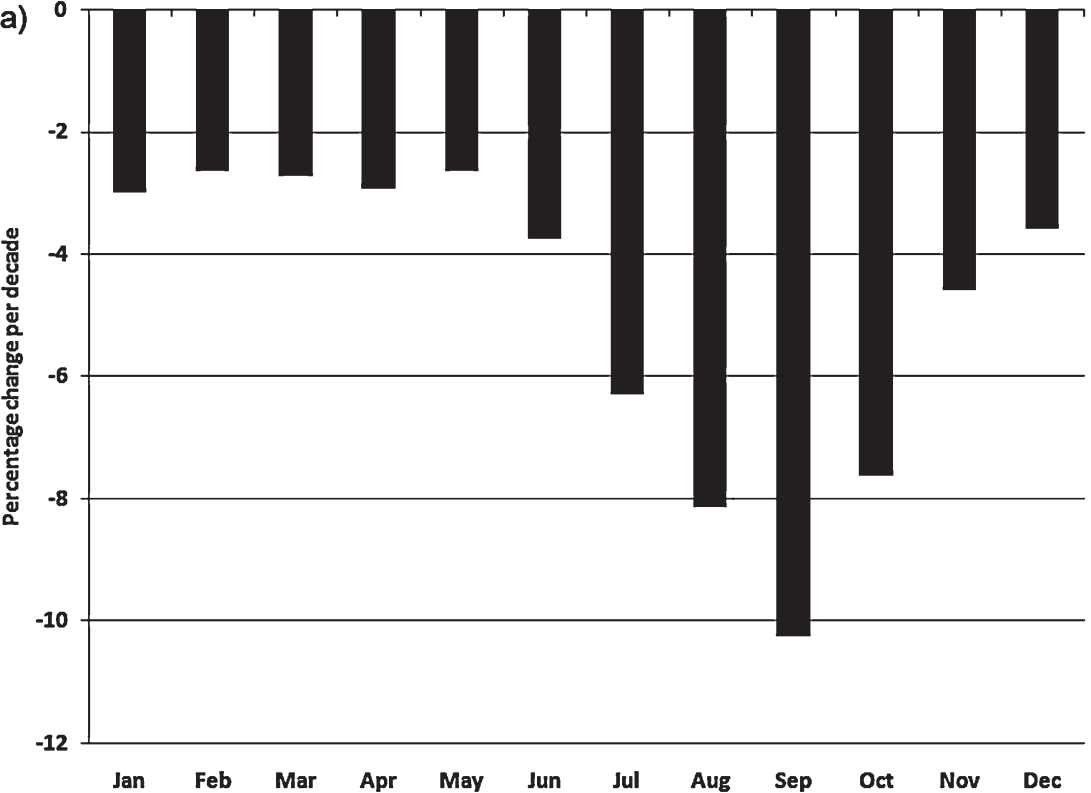

(b)

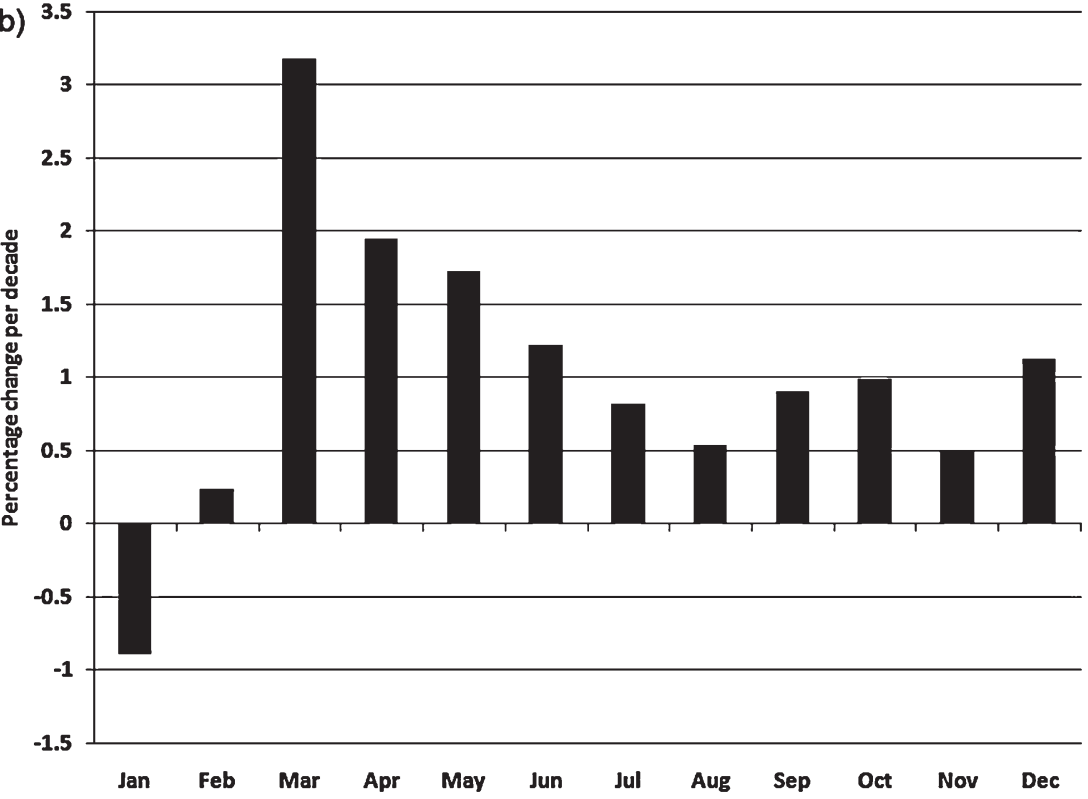

Fig. 8 The annual cycle of percentage change of sea-ice extent in (a) the Arctic and (b) the Antarctic. Based on the National Aeronautics and Space Administration Bootstrap sea-ice extent retrieval algorithm. (From Turner et al. 2009.) 


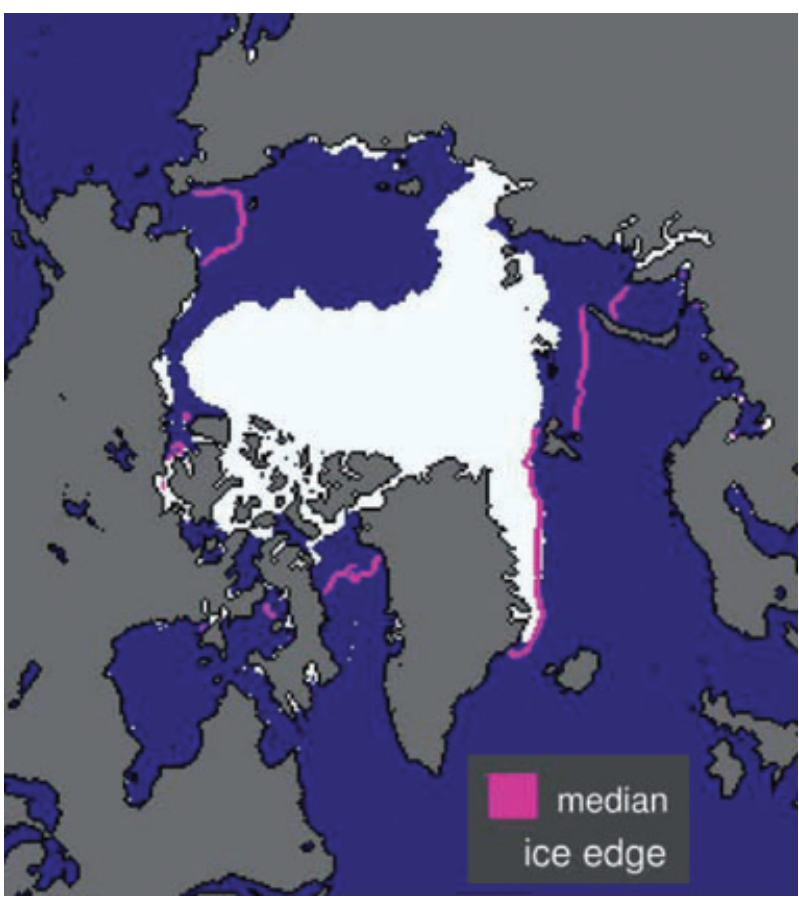

Fig. 9 The minimum Arctic sea-ice extent in October 2007 (white area), relative to climatology (purple line). (From Fetterer 2002 [updated 2009].)

area of perennial sea ice over the Arctic Ocean decreased from over 5.6 million $\mathrm{km}^{2}$ to 2.7 million $\mathrm{km}^{2}$, as sea ice drifted away at twice its usual speed.

Sea ice may reside in the Arctic for over 5 years, but it is strongly influenced by the state of the NAM, with increased ice advection away from the Russian coast during high NAM periods, and faster export of sea ice from the pole to the Fram Strait. During summers with high NAM (June-August), ice motion increases the concentration of sea ice, and temperature advection increases the concentration of ice in the Chukchi Sea, but decreases the concentration of ice in the Canadian Beaufort Sea.

The NAM peaked around 1989-1995, and since then a more meridional circulation pattern (southerly wind anomalies from the Pacific sector) has been present. These NAM and meridional flows persisted for multiple years, contributing to large-scale changes in ocean and sea-ice conditions (Shimada et al. 2006; Steele et al. 2008). Despite the switch of the NAM to more neutral conditions, the Arctic sea-ice extent has continued to decrease, suggesting that the correlation between the NAM and Arctic climate that characterized the 20th century may now be broken.

The recently observed reduction in sea-ice cover in the Arctic Ocean is not spatially uniform, but rather is disproportionately large in the Pacific sector of the Arctic Ocean. The spatial pattern of ice reduction is similar to the spatial distribution of warm Pacific Summer Water that crosses the upper portion of the halocline in the southern Canada Basin, north of the Chukchi Sea.

In 2007 the sea-ice minimum was reached as a result of favourable synoptic conditions, with the loss of sea ice on the Pacific side resulting from an unusually persistent surface high pressure/southerly wind pattern from June through to August, which transported heat and moisture into the central Arctic, north of the Bering Strait. The high pressure over the Beaufort Sea produced fewer clouds, but because of the albedo of existing ice cover in this region, it did not impact on the area of major sea-ice loss further to the west (Schweiger et al. 2008). The winds also advected sea ice across the central Arctic towards the Atlantic sector (Gascard et al. 2008). A similar pressure pattern also occurred in 1977 and 1987, with no remarkable effect on sea-ice extent. Warm Pacific water entering the Arctic Ocean via the Chukchi Sea also appears to have been important in the 2007 sea-ice minimum. There has been a great deal of debate as to whether the minimum of Arctic ice extent in 2007 was a result of anthropogenic factors, or whether it could have occurred because of natural climate variability. There were warmer air temperatures across many high-latitude areas during the 1930s, but there was not a decrease of Arctic sea ice on the scale of that seen in the early years of the 21 st century. At a workshop on recent highlatitude climate change in Seattle in October 2007, the participants concluded that the dramatic Arctic sea-ice loss in 2007 was caused by a combination of temperature increases as a result of a greater concentration of greenhouse gases, fortuitous timing in the natural variability of the atmospheric general circulation and positive feedbacks associated with a reduction in sea ice.

When run through the 21 st century, some of the climate models used in the production of the IPCC fourth assessment report (Solomon et al. 2007) do have sea-ice extent decreases of the magnitude observed in recent years, although all the models do this much more slowly than is observed in the real world (Stroeve et al. 2007). Representing rather small-scale atmospheric and oceanic processes and feedbacks in a climate model is extremely challenging.

The Antarctic. In contrast to the Arctic, the extent of Southern Hemisphere sea ice has actually increased in the period since reliable satellite data became available in 1979. The increase has been statistically significant, and has been greatest in March (Fig. 8b) and in the Ross Sea sector of the Southern Ocean. The change in this area had been linked to a stronger cyclonic flow over West Antarctica, giving greater southerly flow off the Ross Ice Shelf 
(Stammerjohn, Martinson, Smith \& Iannuzzi 2008). This change in circulation was reflected in the ECMWF 40-year reanalysis (ERA-40) and the AR4 models run through the late 20th century. Experiments with an atmosphere-only model have pointed to the springtime decrease of stratospheric ozone as playing a major role in changing the atmospheric circulation over the Amundsen Sea (Turner et al. 2009).

\section{The ice sheets}

The Greenland ice sheet. Recent changes in the Greenland ice sheet have received a great deal of attention in the scientific literature, as well as in the popular press, but estimating the net change in the mass of ice locked into the ice sheet is very difficult. Much of the ice sheet is at high elevations, where temperatures remain below zero throughout the year, so with regional temperatures increasing (Cappelen 2004) it is estimated that the accumulation here has increased in recent decades (Box et al. 2006). However, at lower elevations there is evidence of greater ablation, which has been observed by airborne laser altimeters (Krabill et al. 2000). The greater ablation is resulting in more water on the surface of the ice sheet during summer and greater run-off (Hanna et al. 2008). Overall, this pattern of change is thought to produce a negligible trend in the total surface mass balance of the ice sheet (Box et al. 2006), but as the ice sheet rests on rock, the additional run-off will directly contribute to the rise in sea level. How much Greenland is contributing to sea-level rise is difficult to estimate. The sea level is rising as a result of both thermal expansion and the melting of glacier ice, with both sources contributing about half each to the observed rise. For the period 1961-2003 the observed contribution resulting from thermal expansion was $0.42 \mathrm{~mm}$ per year, with total glacier melt (ice sheets, ice caps and small glaciers) adding $0.69 \mathrm{~mm}$ per year (Solomon et al. 2007). In recent years the rise in sea level has accelerated, and over 1993-2003 the contribution from these two sources increased to $1.60 \mathrm{~mm}$ per year and $1.19 \mathrm{~mm}$ per year, respectively (Solomon et al. 2007). Estimates vary slightly over how much Greenland is contributing to the current rise in sea level, but best estimates are that it accounts for 20-30\% of the total sea-level rise (Meier et al. 2007).

The Antarctic ice sheet. As discussed earlier, outside of the Antarctic Peninsula temperature changes across the continent have been rather small over the last 50 years, and since about 1980 there has even been a small cooling along the coast of East Antarctica. Not surprisingly, when coupled with the low temperatures that are experienced on the Antarctic Plateau, there is little evidence for melting of the ice sheet across most of the continent. Analysis of the available accumulation data also suggests that there has not been any significant change in snowfall across the continent over the last 50 years (Monaghan et al. 2006). However, two areas have exhibited marked change in recent decades. The rise in temperature across the Antarctic Peninsula has resulted in the disintegration of a number of floating ice shelves, including the Larsen-B ice shelf in 2002, when $3250 \mathrm{~km}^{2}$ of shelf ice on the eastern side of the peninsula disintegrated into many small fragments over a period of months, releasing 500 billion tonnes of ice into the Southern Ocean. Of course, this ice was already floating, so there was no impact on sea level. However, a recent study of the glaciers around the coast of the peninsula has shown that over the last 50 years $87 \%$ of the 244 glaciers studied had retreated, and that the average retreat rates have accelerated (Cook et al. 2005).

The second major area where change has been observed is in the Pine Island and Thwaites Glacier region of West Antarctica. The Pine Island Glacier is an extremely important part of the West Antarctic ice sheet, as it discharges 75 giga tonnes per year of ice into the Southern Ocean, which is the largest discharge of any ice stream in West Antarctica. Satellite altimeter measurements have shown a major thinning of the ice sheet in the Pine Island region (Davis et al. 2005), with satellite radar interferometry data showing that the grounding line retreated $5 \mathrm{~km}$ inland between 1992 and 1996 (Rignot 1998). A recent analysis (Rignot et al. 2008) using interferometry data found that ice sheet losses from coastal West Antarctica had increased by 59\% in the 10 years to 2006. Atmospheric temperatures in the Amundsen Sea embayment rarely reach melting point, and it is very unlikely that changes in atmospheric conditions have directly played a role in the loss of ice. Rather, it is most likely that a change in ocean circulation is responsible for the loss of ice, with relatively warm circumpolar deep water (CDW) on the continental shelf playing a role (Thoma et al. 2008). However, changes in atmospheric circulation related to the movement of the Amundsen Sea Low may have indirectly contributed to the variability in the delivery of CDW to the Pine Island area. Melt in this area is thought to be responsible for most of the Antarctic contribution to recent sea-level rise, which accounts for $10-20 \%$ of the total rise.

\section{Attribution of the observed changes}

Formal attribution of ongoing changes in the Arctic is difficult because natural variability is large. However, evidence of an anthropogenic influence is emerging (Gillett 
et al. 2009). Analysis of model simulations provided to the IPCC shows that the inclusion of increasing greenhouse gases is essential to realistically represent the observed Arctic temperature increases during recent decades. This contrasts with the warm period during the 1930s that Wang et al. (2007) argue was caused by internal climate variability. Other evidence consists of multiple indicators, including increased temperatures, diminished sea ice, degraded permafrost, enlarged melt area on Greenland, increased water vapour, decreased snow extent, increased river discharge and the resulting ecosystem impacts.

It is difficult to attribute a single event, such as the record minimum extent of Arctic sea ice in September 2007, to anthropogenic climate change. However, there are several lines of evidence that support this conclusion. The 2007 ice loss greatly exceeded that in any other year in the observational record. Control runs of global climate models with no anthropogenic forcing do not exhibit similar events, but large year-on-year decreases are simulated in some ensemble members with anthropogenic forcing.

In the Antarctic, the strengthening of the westerly winds that has taken place as a result of the shift of the SAM into its positive phase is consistent with the simulated response to external forcing from stratospheric ozone depletion and greenhouse gas increases. It has also been shown that the resultant warming on the eastern side of the Antarctic Peninsula and the break-up of several ice shelves can be attributed, at least in part, to anthropogenic influence. There is also increasing evidence that the broadscale warming of the Southern Ocean is a result of anthropogenic forcing, combined with natural variability (Levitus et al. 2005).

\section{Prospects for the next century}

Although the two polar regions have shown many contrasting features of change over recent decades, our best estimates are that by the end of the 21 st century the similarities of change will be greater than the differences.

Producing reliable predictions of how the Antarctic climate will evolve over the next century is not easy, especially as many models have great difficulty in reproducing recent changes. For example, Monaghan, Bromwich \& Schneider (2008) found that a representative sample of IPCC models predicted the Antarctic to be warming at the global rate, whereas the rate of warming is much lower in reality. Nevertheless, the IPCC models do provide useful, broad guidance on how the climate will change in the future, although it is not possible to put much weight on regional detail.
Bracegirdle et al. (2008) used the IPCC predictions to examine how a number of aspects of the Antarctic climate system may change in the future. They found that temperatures across the Antarctic were expected to increase by about $0.33 \pm 0.1^{\circ} \mathrm{C}$ per decade on land and $0.26 \pm 0.1^{\circ} \mathrm{C}$ per decade in the ocean/sea-ice zone, which is approximately the same change as the mean change for the land areas of the Earth. Where sea ice is lost around East Antarctica the warming is predicted to be about $0.5^{\circ} \mathrm{C}$ per decade. Larger increases in annual mean temperature are expected across the Arctic, with values of $0.6-0.8^{\circ} \mathrm{C}$ per decade over the northern parts of the continents, and the largest values of $1^{\circ} \mathrm{C}$ per decade over the Arctic Ocean (Solomon et al. 2007). However, it appears that the real world is on a faster trajectory of Arctic sea-ice loss than the expected value projected by IPCC models, so great care must be exercised in using model output. It is thus important to understand that although many of the IPCC projections are based on averages of model runs, reality is but a single realization. As Arctic sea-ice extent is declining faster than forecast by climate models, a goal has to be to develop a framework for describing climate model uncertainty in sea-ice retreat. The IPCC's fourth assessment report models have a very wide range of projections for sea-ice evolution over the next century, and a major target must be to reduce this uncertainty.

There has been a great deal of discussion about if and when the Arctic Ocean will become ice-free in the summer during the present century. If the changes seen in recent years are indicative of what will happen in the future, there could be a nearly ice-free summer Arctic before 2030, as suggested by Stroeve et al. (2008). It should be noted that some scientists feel that even this date is too conservative.

With such large changes in Arctic sea-ice extent in recent years it is interesting to consider whether there are any possible brakes on the system. Polar amplification of global warming may slow the poleward transport of sensible heat, but the transport of latent heat may increase. Arctic cloud cover is increasing during winter, and decreasing during other seasons. However, over the Arctic Ocean the "shading effect" will be small because of the low contrast between clouds and ice/snow. Increased precipitation-evaporation may slow the thermohaline circulation, but model results imply a constant or even increasing flow of warm AW into the Arctic Ocean.

In the south, the recent increase in Antarctic sea-ice extent is expected to peak within the next decade or two as greenhouse gas levels rise and stratospheric ozone levels recover. By the end of the century there is expected to be a reduction in the Antarctic sea-ice area of about $33 \%$, over the year as a whole, and a $25 \%$ reduction of sea-ice extent (Bracegirdle et al. 2008). 
In the Antarctic, the future recovery of stratospheric ozone concentrations will weaken the positive trend in the SAM index, and will provide less of a mask to greenhouse gas impacts on warming across the continent and the sea-ice zone, thereby promoting sea-ice loss (Perlwitz et al. 2008). A continued increase in greenhouse gases, however, has two effects: it contributes to maintaining the positive trend in the SAM index, and also augments the surface energy balance. Which effect will dominate the coming decades is a question of ongoing research (Keeley et al. 2007).

The states of the Arctic and Antarctic climate systems are the result of complex interactions between external forcing, large-scale nonlinear climate dynamics and regional feedbacks. However, given the recent dramatic loss of multiyear sea ice in the north, and the projections of continued global warming, it seems nearly impossible for summer Arctic sea ice to return to its climatological extent of prior to 1980 .

Over the next century models suggest an increase of snowfall across the Antarctic of $25-50 \%$, with a switch of $10 \%$ of snowfall to rain in summer. The winter warming of the Antarctic Peninsula is expected to continue as a result of reduced sea-ice extent, and similar warming will spread to many other coastal regions. A widespread increase of the circumpolar westerlies is expected, leading to a decrease of coastal easterlies, particularly in summer and autumn. The models suggest westerlies over the Southern Ocean will increase by $10-20 \%$, but it is not expected that there will be large changes in winds over the continent. However, most of Antarctica will remain well below freezing, so there will be no largescale melting of the ice sheet. However, a major uncertainty is what will happen in the Amundsen Sea sector of the West Antarctic ice sheet. Recent observations have shown that this is currently the most rapidly changing region of the entire Antarctic ice sheet, with an acceleration of flow caused by the basal melting of its ice shelf and subsequent grounding line retreat of Pine Island Glacier. The fear is that continued melting in this sector will result in the enhanced flow of ice from the interior of the ice sheet.

\section{Conclusions}

The two polar regions have experienced markedly different climatic changes in recent decades, at a time when they were subject to near identical solar forcing and increases in greenhouse gas levels. Initially, this may seem to suggest a paradox, but they are largely consistent with the known oceanic and atmospheric dynamics acting on contrasting topography, land/sea distribution and regional environmental factors. The recent changes at both poles, although different, are consistent with known impacts from shifts in atmospheric circulation and from thermodynamic processes that are, in turn, a consequence of anthropogenic influences on the climate system.

Changes in the annular modes have played an important role in the decadal variability for both polar regions. The SAM has been important in driving many of the climatic changes observed across the Antarctic and Southern Ocean, such as the increase in westerly winds and isolating the interior of the continent. The SAM has shifted into its positive phase over recent decades, as a result of the ozone hole, increasing greenhouse gases and natural factors, such as volcanic aerosols, but the ozone hole has been the most important factor, and it is now known to be responsible for the warming on the eastern side of the Antarctic Peninsula. In the north, the NAM was responsible for much of the flushing of sea ice from the Arctic Ocean in the 1990s, which helped to precondition the region for the large losses of sea ice in the first decade of the 21 st century. However, the link between the NAM and sea-ice extent now seems to be broken, suggesting that other factors have played the largest part in the recent ice minima.

To better understand the climate changes that have taken place over recent decades, and to produce improved projections for the next century, we need better coupled atmosphere-ocean-cryosphere models. Yet the polar climate systems involve complex interactions between the different parts of the system, and there are numerous feedbacks (e.g., ice albedo and aerosolradiation-circulation). Incorporating such processes into the models is a major challenge, but this must be achieved if we are to understand how the environments of the polar regions will evolve in the future, under increasing levels of greenhouse gas emission. The fact that climate models are generally too slow in replicating the recent large losses of ice is a worrying factor in our attempts to simulate the Arctic climate system.

In recent years we have seen some remarkable changes in both polar regions. Our understanding of the mechanisms behind these events is improving; however, the complex interactions between the atmosphere, ocean and cryosphere are difficult to unravel, and even more difficult to model. The future, no doubt, holds more surprises, and it is essential that we obtain greater predictive capability in order to understand what will happen in these two climatically critical regions. Changes are occurring faster than was anticipated, even a few years ago. We need to proceed with dispatch in using all observational and modelling tools to promote the understanding of the further potential for high-latitude impacts. 


\section{Acknowledgements}

This paper draws on the discussions at the Recent High Latitude Climate Change workshop, held at the Pacific Marine Environment Laboratory (PMEL), Seattle, WA, in October 2007. We are grateful to the scientists who participated and the management of PMEL for hosting the meeting. We would also like to thank the Scientific Committee on Antarctic Research, the International Arctic Science Council, the Climate and Cryosphere project of the World Climate Research Programme, the International Commission on Polar Meteorology and the NOAA Arctic Program for supporting the workshop.

\section{References}

Abdul A.O. \& Burn D.H. 2006. Trends and variability in the hydrological regime of the Mackenzie River Basin. Journal of Hydrology 319, 282-294.

Aoki S. 2002. Coherent sea level response to the Antarctic Oscillation. Geophysical Research Letters 29, article no. 1950, doi: 10.1029/2002GL015733.

Arblaster J. \& Meehl G.A. 2006. Contributions of external forcings to Southern Annular Mode trends. Journal of Climate 19, 2896-2905.

Baldwin M.P. 2001. Annular modes in global daily surface pressure. Geophysical Research Letters 28, 4115-4118.

Box J.E., Bromwich D.H., Veenhuis B.A., Bai L.S., Stroeve J.C., Rogers J.C., Steffen K., Haran T. \& Wang S.H. 2006. Greenland ice sheet surface mass balance variability (1988-2004) from calibrated polar MM5 output. Journal of Climate 19, 2783-2800.

Bracegirdle T.J., Connolley W.M. \& Turner J. 2008. Antarctic climate change over the twenty first century. Journal of Geophysical Research-Atmospheres 113, D03103, doi: 10.1029/2007JD008933.

Cappelen J. 2004. Yearly mean temperature for selected meteorological stations in Denmark, the Faroe Islands and Greenland: 1873-2003. Technical Report 04-07. Copenhagen: Danish Meteorological Institute.

Chapman W.L. \& Walsh J.E. 2007. A synthesis of Antarctic temperatures. Journal of Climate 20, 4096-4117.

Comiso J.C. \& Nishio F. 2007. Trends in the sea ice cover using enhanced and compatible AMSR-E, SSM/I and SMMR data. Journal of Geophysical Research-Oceans 113, C02S07, doi: 10.1029/2007JC004257.

Cook A.J., Fox A.J., Vaughan D.G. \& Ferrigno J.G. 2005. Retreating glacier fronts on the Antarctic Peninsula over the past half-century. Science 308, 541-544.

Davis C.H., Li Y.H., McConnell J.R., Frey M.M. \& Hanna E. 2005. Snowfall-driven growth in East Antarctic ice sheet mitigates recent sea-level rise. Science 308, 1898-1901.

Déry S.J., Stieglitz M., McKenna E.C. \& Wood E.F. 2005. Characteristics and trends of river discharge into Hudson, James, and Ungava bays, 1964-2000. Journal of Climate 18, 2540-2557.
Dickson R.R., Meincke J., Malmberg S.-A. \& Lee A.J. 1988. The "Great Salinity Anomaly" in the northern North Atlantic 1968-1982. Progress in Oceanography 20, 103-151. Farman J.C., Gardiner B.G. \& Shanklin J.D. 1985. Large losses of total ozone in Antarctica reveal seasonal CClOx/ NOx interaction. Nature 315, 207-210.

Fetterer F., Knowles K., Meier W. \& Savoie M. 2002, updated 2009. Sea Ice Index, 16 October 2007. Boulder, CO: National Snow and Ice Data Center. Digital media. Available at http://nsidc.org/news/press/2007_ seaiceminimum/images/20071017_extent.png.

Fogt R.L. \& Bromwich D.H. 2006. Decadal variability of the ENSO teleconnection to the high latitude South Pacific governed by coupling with the Southern Annular Mode. Journal of Climate 19, 979-997.

Fyfe J.C. 2006. Southern Ocean warming due to human influence. Geophysics Research Letters 33, L19701, doi: 10.1029/2006GL027247.

Fyfe J.C., Boer G.J. \& Flato G.M. 1999. The Arctic and Antarctic oscillations and their projected changes under global warming. Geophysics Research Letters 26, 1601-1604.

Fyfe J.C. \& Saenko O.A. 2006. Simulated changes in the extratropical Southern Hemisphere winds and currents. Geophysics Research Letters 33, L06701, doi: 10.1029/ 2005 GL025332.

Gascard J.C., Festy J., le Gogg H., Weber M., Bruemmer B., Offermann M., Doble M., Wadhams P., Forsberg R., Hanson S., Skourup H., Gerland S., Nicolaus M., Metaxin J.-P., Grangeon J., Haapala J., Rinn E., Haas C., Heygster G., Jakobson E., Palo T., Wilkinson J., Kaleschke L., Claffey K. J., Elder B. \& Bottenheim J. 2008. Exploring Arctic transpolar drift during dramatic sea ice retreat. EOS, Transactions of the American Geophysical Union 89, 21-28.

Gille S.T. 2002. Warming of the Southern Ocean since the 1950s. Science 295, 1275-1277.

Gille S.T. 2003. Float observations of the Southern Ocean. Part 1. Estimating mean fields, bottom velocities and topographic steering. Journal of Physical Oceanography 33, 1167-1181.

Gille S.T. 2008. Decadal-scale temperature trends in the Southern Hemisphere Ocean. Journal of Climate 21, 4749-4765.

Gillett N.P., Stone D.A., Stott P.A., Nozawa T., Karpechko A.Y., Hegerl G.C., Wehner M.F. \& Jones P.D. 2009.

Attribution of polar warming to human influence. Nature Geoscience 1, 760-764.

Gillet N.P. \& Thompson D.W.J. 2003. Simulation of recent Southern Hemisphere climate change. Science 302, 273-275.

Hall A. \& Visbeck M. 2002. Synchronous variability in the Southern Hemisphere atmosphere, sea ice, and ocean resulting from the Annular Mode. Journal of Climate 15, 3043-3057.

Hanna E., Huybrechts P., Steffen K., Cappelen J., Huff R., Shuman C., Irvine-Fynn T., Wise S. \& Griffiths M. 2008. Increased run-off from melt from the Greenland Ice Sheet: a response to global warming. Journal of Climate 21(2), 331-341. 
Helsen M.M., van den Broeke M.R., van de Wal R.S.W., van De Berg W.J., Van Meijgaard E., Davis C.H., Li Y.H. \& Goodwin I. 2008. Elevation changes in Antarctica mainly determined by accumulation variability. Science 320, 1626-1629.

Hoerling M.P., Hurrell J.W. \& Xu T. 2001. Tropical origins for recent North Atlantic climate change. Science 292, 90-92.

Hoerling M.P., Hurrell J.W., Xu T., Bates G.T. \& Phillips A.S. 2004. Twentieth century North Atlantic climate change. Part II. Understanding the effect of Indian Ocean warming. Climate Dynamics 23, 23 391-23 405.

Hogg A.M., Meredith M.P., Blundell J.R. \& Wilson C. 2008. Eddy heat flux in the Southern Ocean: response to variable wind forcing. Journal of Climate 21, 608-620.

Hughes C.W., Woodworth P.L., Meredith M.P., Stepanov V., Whitworth T. \& Pyne A.R. 2003. Coherence of Antarctic sea levels, Southern Hemisphere Annular Mode, and flow through Drake Passage. Geophysical Research Letters 30, article no. 1464, doi: 10.1029/2003GL017240.

Jacobs S.S., Giulivi C.F. \& Mele P.A. 2002. Freshening of the Ross Sea during the late 20th century. Science 297, 386-389.

Johannessen O.M., Bengtsson L., Miles M.W., Kuzmina S.I., Semenov V.A., Alekseev G.V., Nagurnyi A.P., Zakharov V.F., Bobylev L.P., Pettersson L.H., Hasselmann K. \& Cattle H.P. 2004. Arctic climate change: observed and modelled temperature and sea-ice variability (vol. 56A, p. 328, 2004). Tellus Series A-Dynamic Meteorology and Oceanography 56, 328-341.

Johanson C.M. \& Fu Q. 2007. Antarctic atmospheric temperature trend patterns from satellite observations. Geophysics Research Letters 34, L12703, doi: 10.1029/ 2006 GL029108.

Jones J.M. \& Widmann M. 2003. Instrument- and tree-ring-based estimates of the Antarctic Oscillation. Journal of Climate 16, 3511-3524.

Keeley S.P.E., Gillett N.P., Thompson D.W.J., Solomon S. \& Forster P.M. 2007. Is Antarctic climate most sensitive to ozone depletion in the middle or lower stratosphere? Geophysics Research Letters 34, L22812, doi: 10.1029/ 2007GL031238.

Kidson J.W. 1999. Principal modes of Southern Hemisphere low-frequency variability obtained from NCEP-NCAR reanalyses. Journal of Climate 12, 2808-2830.

King J.C. 1994. Recent climate variability in the vicinity of the Antarctic Peninsula. International Journal of Climatology 14, 357-369.

Krabill W., Abdalati W., Frederick E., Manizade S., Martin C., Sonntag J., Swift R., Thomas R., Wright W. \& Yungel J. 2000. Greenland ice sheet: high-elevation balance and peripheral thinning. Science 289, 428-430.

Kushner P.J., Held I.M. \& Delworth T.L. 2001. Southern Hemisphere atmospheric circulation response to global warming. Journal of Climate 14, 2238-2249.

Le Quéré C., Rodenbeck C., Buitenhuis E.T., Conway T.J., Langenfelds R., Gomez A., Labuschagne C., Ramonet T.,
Nakazawa T., Metzl N., Gillett N.P. \& Heimann M. 2007. Saturation of the Southern Ocean $\mathrm{CO}_{2}$ sink due to recent climate change. Science 316, 1735-1738.

Levitus S., Antonov J. \& Boyer T. 2005. Warming of the world ocean, 1955-2003. Geophysics Research Letters 32, L02604, doi: 10.1029/2004GL021592.

Marshall G.J. 2003. Trends in the Southern Annular Mode from observations and reanalyses. Journal of Climate 16, 4134-4143.

Marshall G.J., Orr A., van Lipzig N.P.M. \& King J.C. 2006. The impact of a changing Southern Hemisphere Annular Mode on Antarctic Peninsula summer temperatures. Journal of Climate 19, 5388-5404.

Marshall G.J., Stott P.A., Turner J., Connolley W.M., King J.C. \& Lachlan-Cope T.A. 2004. Causes of exceptional atmospheric circulation changes in the Southern Hemisphere. Geophysics Research Letters 31, L14205, doi: 10.1029/2004GL019952.

Mayewski P.A. \& Maasch K.A. 2006. Recent warming inconsistent with natural association between temperature and atmospheric circulation over the last 2000 years. Climate of the Past Discussions 2, 327-355.

Meier M.F., Dyurgerov M.B., Rick U.K., O'Neel S., Pfeffer W.T., Anderson R.S., Anderson S.P. \& Glazovsky A.F. 2007. Glaciers dominate eustatic sea-level rise in the $21 \mathrm{st}$ century. Science 317, 1064-1067.

Meredith M.P. \& Hogg A.M. 2006. Circumpolar response of Southern Ocean eddy activity to a change in the Southern Annular Mode. Geophysics Research Letters 33, L16608, doi: 10.1029/2006GL026499.

Meredith M.P. \& King J.C. 2005. Climate change in the ocean to the west of the Antarctic Peninsula during the second half of the 20th century. Geophysics Research Letters 32, L19606, doi: 10.1029/2005GL024042.

Meredith M.P., Woodworth P.L., Hughes C.W. \& Stepanov V. 2004. Changes in the ocean transport through Drake Passage during the 1980s and 1990s, forced by changes in the Southern Annular Mode. Geophysics Research Letters 31, L21305, doi: 10.1029/2004GL021169.

Min S.K., Zhang X.B. \& Zwiers F. 2008. Human-induced Arctic moistening. Science 320, 518-520.

Monaghan A.J. \& Bromwich D.H. 2008. Advances in describing recent Antarctic climate variablity. Bulletin of the American Meteorological Society 89, 1295-1306.

Monaghan A.J., Bromwich D.H., Chapman W.L. \& Comiso J.C. 2008. Recent variability and trends of Antarctic near-surface temperature. Journal of Geophysical Research 113, D04105, doi: 10.1029/2007JD009094.

Monaghan A.J., Bromwich D.H., Fogt R.L., Wang S.-H., Mayewski P.A., Dixon D.A., Ekaykin A., Frezzotti M., Goodwin I., Isaksson E., Kaspari S.D., Morgan V.I., Oerter H., van Ommen T.D., van der Veen C.J. \& Wen J. 2006. Insignificant change in Antarctic snowfall since the International Geophysical Year. Science 313, 827-831.

Monaghan A.J., Bromwich D.H. \& Schneider D.P. 2008. Twentieth century Antarctic air temperature and snowfall 
simulations by IPCC climate models. Geophysics Research Letters 35, L07502, doi: 10.1029/2007GL032630.

Morison J.H., Aagaard K., Falkner K.K., Hatakeyama K., Moritz R., Overland J.E., Perovich D.K., Shimada K., Steele M., Takizawa T. \& Woodgate R. 2002. North Pole environmental observatory delivers early results. EOS, Transactions of the American Geophysical Union 83, 357-361.

Nghiem S.V., Rigor I.G., Perovich D.K., Clemente-Colon P., Weatherly J.W. \& Neumann G. 2007. Rapid reduction of Arctic perennial sea ice. Geophysics Research Letters 34, L19504, doi: 10.1029/2007GL031138.

Oke P.R. \& England M.H. 2004. Oceanic response to changes in the latitude of the Southern Hemisphere subpolar westerly winds. Journal of Climate 17, 1040-1054.

Overland J.E., Spillane M.C., Percival D.B., Wang M. \& Mofjeld H.O. 2004. Seasonal and regional variation of pan-Arctic surface air temperature over the instrumental record. Journal of Climate 17, 23 263-23 282.

Overland J.E., Wang M. \& Salo S. 2008. The recent Arctic warm period. Tellus Series A-Dynamic Meteorology and Oceanography 60, 589-597.

Perlwitz J., Pawson S., Fogt R.L., Nielsen J.E. \& Neff W.D. 2008. Impact of stratospheric ozone hole recovery on Antarctic climate. Geophysics Research Letters 35, L08714, doi: 10.1029/2008GL033317.

Peterson B.J., Holmes R.M., McClelland J.W., Vorosmarty C.J., Lammers R.B., Shiklomanov A.I., Shiklomanov I.A. \& Rahmstorf S. 2008. Increasing river discharge to the Arctic Ocean. Science 298, 2171-2173.

Pezza A.B., Durrant T., Simmonds I. \& Smith I. 2008. Southern Hemisphere synoptic behavior in extreme phases of SAM, ENSO, sea ice extent and southern Australia rainfall. Journal of Climate 21, 5566-5584.

Quadrelli R. \& Wallace J.M. 2002. Dependence of the structure of the Northern Hemisphere annular mode on the polarity of ENSO. Geophysical Research Letters 29, 2132-2135.

Randel W.J. \& Wu F. 1999. Cooling of the Arctic and Antarctic polar stratospheres due to ozone depletion. Journal of Climate 12, 1467-1479.

Rignot E.J. 1998. Fast recession of a West Antarctic glacier. Science 281, 549-551.

Rignot E., Bamber J.L., van den Broeke M.R., Davis C., Li Y.H., van de Berg W.J. \& van Meijgaard E. 2008. Recent Antarctic ice mass loss from radar interferometry and regional climate modelling. Nature Geoscience 1, 106-110.

Rintoul S.R. 2007. Rapid freshening of Antarctic Bottom Water formed in the Indian and Pacific oceans. Geophysics Research Letters 34, L06606, doi: 10.1029/2006GL028550.

Schweiger A., Zhang J., Lindsay R.W. \& Steele M. 2008. Did unusually sunny skies help drive the record sea ice minimum? Geophysics Research Letters 35, L10503, doi: 10.1029/2008GL033463.

Serreze M.C., Walsh J.E., Chapin F.S., Osterkamp T., Dyurgerov M., Romanovsky V.E., Oechel W., Morison J. \& Barry R.G. 2000. Observational evidence of recent change in the northern high-latitude environment. Climate Change 46, 159-207.
Sexton D.M.H. 2001. The effect of stratospheric ozone depletion on the phase of the Antarctic Oscillation. Geophysics Research Letters 28, 3697-3700.

Shimada K., Komashida T., Itoh M., Nishino S., Carmack E., McLaughlin F.A., Zimmermann S. \& Proshutinsky A. 2006 Pacific Ocean inflow: influence on catastrophic reduction of sea ice cover in the Arctic Ocean. Geophysics Research Letters 33, L08605, doi: 10.1029/2005GL025624.

Simmonds I. 2003. Modes of atmospheric variability over the Southern Ocean. Journal of Geophysical Research-Oceans 108, article no. 8078, doi: 10.1029/2000JC000542.

Simmonds I., Burke C. \& Keay K. 2008. Arctic climate change as manifest in cyclone behavior. Journal of Climate 21, 5777-5796.

Simmonds I. \& Jacka T.H. 1995. Relationships between the interannual variability of Antarctic sea ice and the Southern Oscillation. Journal of Climate 8, 637-647.

Solomon S., Qin D., Manning M., Chen Z., Marquis M., Averyt K.B., Tignor M. \& Miller H.L. Jr. (eds.) 2007. Climate change 2007. The physical science basis. Contribution of Working Group I to the fourth assessment report of the Intergovernmental Panel on Climate Change. Cambridge: Cambridge University Press.

Stammerjohn S.E., Martinson D.G., Smith R.C. \& Iannuzzi R.A. 2008. Sea ice in the western Antarctic Peninsula region: spatio-temporal variability from ecological and climate change perspectives. Deep-Sea Research Part II 55, 2041-2058.

Stammerjohn S.E., Martinson D.G., Smith R.C., Yuan X. \& Rind D. 2008. Trends in Antarctic annual sea ice retreat and advance and their relation to El Niño-Southern Oscillation and Southern Annular Mode variability. Journal of Geophysical Research-Oceans 113, C03S90, doi: 10.1029/2007JC004269.

Steele M. \& Boyd T. 1998. Retreat of the cold halocline layer in the Arctic Ocean. Journal of Geophysical Research-Oceans 103, $10419-10435$.

Steele M., Ermold W. \& Zhang J. 2008. Arctic Ocean surface warming trends over the past 100 years. Geophysics Research Letters 35, L02614, doi: 10.1029/2007GL031651.

Steig E.J., Schneider D.P., Rutherford S.D., Mann M.E., Comiso J.C. \& Shindell D.T. 2009. Warming of the Antarctic ice-sheet surface since the 1957 International Geophysical Year. Nature 457, 459-462.

Stone D.A., Weaver A.J. \& Stouffer R.J. 2001. Projection of climate change onto modes of atmospheric variability. Journal of Climate 14, 3551-3565.

Stroeve J., Holland M.M., Meier W., Scambos T. \& Serreze M.C. 2007. Arctic sea ice decline: faster than forecast. Geophysics Research Letters 34, L09501, doi: 10.1029/ 2007 GL029703.

Stroeve J., Serreze M.C., Drobot S., Gearheard S., Holland M., Maslanik J., Meier W. \& Scambos T. 2008. Arctic sea ice extent plummets in 2007. EOS, Transactions of the American Geophysical Union 89, 13.

Thoma M., Jenkins A., Holland D. \& Jacobs S. 2008. Modelling Circumpolar Deep Water intrusions on the 
Amundsen Sea continental shelf, Antarctica. Geophysical Research Letters 35, L18602, doi: 10.1029/2008GL034939.

Thomas E.R., Marshall G.J. \& McConnell J.R. 2008. A doubling in snow accumulation in the western Antarctic Peninsula since 1850. Geophysics Research Letters 35, L01706, doi: 10.1029/2007GL032529.

Thompson D.W.J. \& Solomon S. 2002. Interpretation of recent Southern Hemisphere climate change. Science 296, 895-899.

Thompson D.W.J. \& Wallace J.M. 2000. Annular modes in the extratropical circulation. Part I. Month-to-month variability. Journal of Climate 13, 1000-1016.

Turner J. 2004. The El Niño-Southern Oscillation and Antarctica. International Journal of Climatology 24, $1-31$.

Turner J., Colwell S.R., Marshall G.J., Lachlan-Cope T.A., Carleton A.M., Jones P.D., Lagun V., Reid P.A. \& Iagovkina S. 2005. Antarctic climate change during the last 50 years. International Journal of Climatology 25, 279-294.

Turner J., Comiso J.C., Marshall G.J., Lachlan-Cope T.A., Bracegirdle T.J., Maksym T., Meredith M.P., Wang Z. \& Orr A. 2009. Non-annular atmospheric circulation change induced by stratospheric ozone depletion and its role in the recent increase of Antarctic sea ice extent. Geophysics Research Letters 36, L08502, doi: 10.1029/2009GL037524.

Turner J., Lachlan-Cope T.A., Colwell S.R., Marshall G.J. \& Connolley W.M. 2006. Significant warming of the Antarctic winter troposphere. Science 311, 1914-1917. van den Broeke M.R. \& van Lipzig N.P.M. 2004. Changes in Antarctic temperature, wind, and precipitation in response to the Antarctic Oscillation. Annals of Glaciology 39, 119-126.

Volodin E.M. \& Galin V.Y. 1999. Interpretation of winter warming on Northern Hemisphere continents in 1977-94. Journal of Climate 12, 2947-2955.

Walker D.P., Brandon M.A., Jenkins A., Allen J.T., Dowdeswell J.A. \& Evans J. 2007. Oceanic heat transport onto the Amundsen Sea shelf through a submarine glacial trough. Geophysics Research Letters 34, L02602, doi: 10.1029/ 2006GL028154.

Wang M., Overland J.E., Kattsov V., Walsh J.E., Zhang X. \& Pavlova T. 2007. Intrinsic versus forced variation in coupled climate model simulations over the Arctic during the 20th century. Journal of Climate 20, 1093-1107.

Yuan X. 2004. ENSO-related impacts on Antarctic sea ice: a synthesis of phenomenon and mechanisms. Antarctic Science 16, 415-425.

Yuan X. \& Li C. 2008. Climate modes in southern high latitudes and their impacts on Antarctic sea ice. Journal of Geophysical Research-Oceans 113, C06S91, doi: 10.1029/ 2006JC004067.

Yuan X.J. \& Martinson D.G. 2000. Antarctic sea ice extent variability and its global connectivity. Journal of Climate 13, 1697-1717.

Zhang Y., Wallace J.M. \& Battisti D.S. 1997. ENSO-like interdecadal variability: 1900-93. Journal of Climate 10, 1004-1020.

Zhu X.J., Sun J.L.K., Liu Z.Y., Liu Q.Y. \& Martin J.E. 2007. A synoptic analysis of the interannual variability of winter cyclone activity in the Aleutian low region. Journal of Climate 20, 1523-1538. 